A highly polymorphic locus on chromosome 11 which has homology to a collagen triple-helix coding sequence

A.J.Brookes, P.H.Hedge and E.Solomon

Department of Somatic Cell Genetics, Imperial Cancer Research Fund, Lincoln's Inn Fields, Holborn, London WC2A 3PX, UK

\title{
SOURCE AND DESCRIPTION OF CLONE
}

Probe 2.1 ; a $4.5 \mathrm{~Kb}$ PstI human genomic DNA fragment subcloned into pEMBL18+ from the insert of cosmid cosHV11. Probe 2.1 contains a degree of homology to the triple-helix coding domain of the chick collagen cDNA pCg54 (1). This property was employed in the initial isolation of cosHV11.

\section{POLYMORPHISM DESCRIBED}

A VNTR type length polymorphism (2) detectable by PstI or HinfI digestion for which the longest and shortest alleles yet observed are 8 and $0.9 \mathrm{~Kb}$ respectively.

\section{FREQUENCY FOR POPULATION STUDIED}

18 distinguishable bands were identified in 15 independent samples of largely European origin. Two bands were observed in all but one of these individuals indicating a heterozygosity of $90 \%$ or greater.

\section{OTHER ENZYMES TESTED}

EcoRI and HindIII were found to give rise to large bands from which the polymorphism was difficult to observe.

\section{CHROMOSOMAL LOCALISATION}

Mapped with somatic cell hybrids and in situ hybridisation to 11p13-15.

\section{MENDELIAN INHERITANCE}

Mendelian inheritance was demonstrated in a three generation family comprising 4 grandparents, 2 parents and 7 children.

\section{PROBE AVAILABILITY}

Available upon request.

\section{OTHER COMMENTS}

The sequence of this polymorphic element has been identified as [ACACTCACCACGG GCACCGGGAGCTGGGGGG] $]_{n}$. Three identical copies of this 31 bp repeat have been determined. Given the original means of its isolation the presence of an equivalent core sequence (shown underlined) to that defined by Nakamura et al (2) is worthy of note.

\section{REFERENCES}

(1) Lehrach, H., Frischauf, A. M., Hanahan, D., Wozney, J., Fuller, F. and Boedtker, H. (1979). Biochem., 18, 3146-3152.

(2) Nakamura, Y., Leppert, M., O'Connell, P., Wolff, R., Holm, T., Culver, M.,

Martin, C., Fujimoto, E., Hoff, M., Kamlin, E. and White, R. (1987). Science, 235 , $1616-1622$.

\section{ACKNOWLEDGEMENTS}

The authors wish to thank Miss T. Jones for her assistance in the chromosomal localisation of probe 2.1 by in situ hybridisation. 